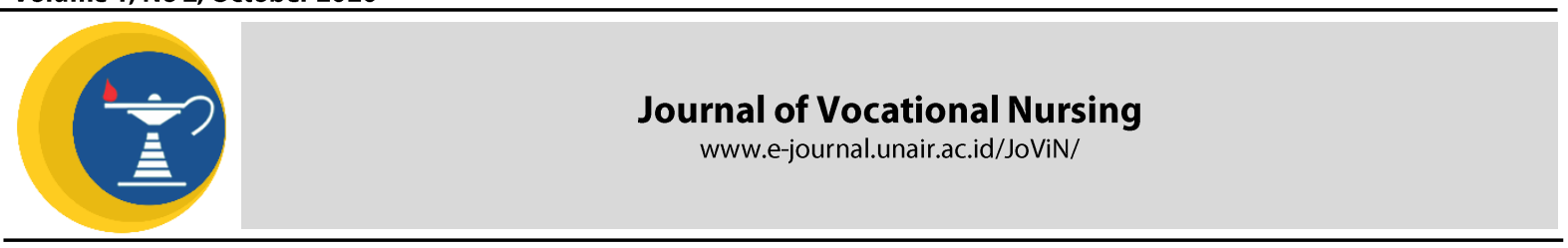

\title{
RELATIONSHIP BETWEEN COPING MECHANISM AND RECURRENCE FREQUENCY IN BRONCHIAL ASTHMA PATIENTS
}

Moh. Jufriyanto ${ }^{1}$ and Endang Fauziyah $\mathrm{S}^{2}$

Research Report

${ }^{1,2}$ Politeknik Negeri Madura

\section{ABSTRACT}

Introduction: Bronchial asthma is a disease that occurs frequently in Indonesia and is reversible and can cause death. The problem that is felt is bouts of shortness of breath when a recurrence occurs. Stress is one of the causes of recurrence. So a positive coping mechanism is needed to prevent relapse. This study aims to determine whether there is a relationship between the coping mechanisms used and the frequency of recurrence in bronchial asthma patients at M. Noer Pamekasan Hospital, 2018. Methods: This research design uses Non-Experimental Analytic Correlation method with a sample of 39 people and uses Probability Simple Random Sampling technique. The research data were taken using a questionnaire. After the tabulation, the data were analyzed using the Rank Spearman test with a significance level of 0.05. Results: The results showed that almost half (45.7\% or 16 people) had maladaptive coping mechanisms and relapses $>5 X /$ month, and a small proportion (11.4\% or 4 people) had adaptive coping mechanisms and relapsed 1-4X / month. From the results of statistical testing, it was found that there was a correlation between coping mechanisms and the frequency of recurrence with a correlation coefficient of 0.430 with a significance level of 0.010 . Conclusion: We know that the coping mechanism is closely related to the occurrence of stress and anxiety in a person. Meanwhile, anxiety is one of the causes of recurrence in bronchial asthma patients. So in providing nursing care, you should not forget about health education about coping mechanisms so that patients can manage the stress experienced so that recurrence of bronchial asthma can be avoided.

\section{ARTICLE INFO}

Recived 16 October 2020

Accepted 25 October 2020

Online 29 October 2020

*Correspondence:

Moh. Jufriyanto

*Email:

eljufrey@gmail.com

\section{Keywords:}

Coping Mechanism, Bronchial Asthma, Patient

\section{INTRODUCTION}

The coping mechanism shows mental and behavioral, to control, tolerate, reduce, or minimize a stressful situation or event. The coping mechanism is defined as a process or way to manage and process psychological pressure (both externally and internally) which consists of efforts, both real action and action in intrapsychic form, such as suppressing emotions, processing input in cognitive (Hasan \& Rufaidah, 2013). One of the negative effects of the maladaptive coping mechanism for patients with bronchial asthma is the emergence of several physiological changes in the body, one of which is a condition that shows hyperactivity in the typical bronchi. The tissue changes in bronchial asthma are uncomplicated, confined to the bronchi, and consist of smooth muscle spasm, mucosal edema, and persistent infiltration of inflammatory cells, and the presence of thick mucus hypersecretion. This condition will cause recurrence in bronchial asthma patients (Miglino et al., 2011). Whereas bronchial asthma itself is a clinical condition characterized by repeated but reversible narrowing of the bronchi, and between episodes of bronchial constriction there is a more normal state of ventilation. In fact, in fulfilling every need, each individual has different efforts and different ways. That's why the stressor received by each individual will be different. There are many bronchial asthma sufferers (patients) who have limitations in stress management, so this will later affect the level of stress that will be experienced by each individual. There is a mechanism that occurs in the body when a stressor is perceived to be stress called the coping mechanism. The stronger our coping mechanism is, the stress can be handled and eliminated as short as possible. So when the 
coping mechanisms are not able to cope with the stress, a relapse often follows afterward. From a temporary study of 10 respondents, it was found that 8 of them felt symptoms of tightness when eating spicy food, especially if they experienced emotional problems such as when they were angry and worried.

From data obtained by the World Health Organization (WHO) released in December 2016, it is estimated that there were 383,000 deaths due to asthma in 2015 (GAN, 2018). The Ministry of Health of the Republic of Indonesia in 2013 found that respiratory system diseases were in the top 10 ranks of the most diseases in outpatients. The national prevalence in that year was $4.5 \%$, while in East Java the prevalence exceeds the national prevalence by $5.3 \%$ (Soetjiningsih, 2015). There were 16 people with asthma with negative perceptions (maladaptive coping mechanism) who had a long healing process at $M$. Noer Pamekasan Hospital who were being treated in 2018. In 2018-2019 there were 39 bronchial asthma patients who were treated at the hospital. M. Noer Pamekasan.

When a person is exposed to a stressor that cannot be handled by their coping mechanisms, stress can no longer be avoided. In this case, the coping mechanism is needed to minimize or even eliminate the stress that occurs. Maladaptive coping will give a high level of stress to the body (Bustam, 2015). In patients with bronchial asthma, this will stimulate the brain to receive a stress response, from the stress response itself, there will be hypersensitivity which secretes excess IgE. It was explained that the IgE molecule binds easily to basophils in the blood. If the IgE molecule binds to the receptor and combines with the reproducing reactive antigen, it can cause the release of chemical media such as histamine which can increase smooth muscle contraction, increase capillary permeability, and increase the activity of respiratory mucosal glands (Sylvia. A P, et al, 2004).
Things like this will stimulate the high incidence of recurrence experienced by bronchial asthma patients. So if this is not addressed early and seriously, it is not impossible if the death rate caused by respiratory diseases (especially bronchial asthma) will soar.

Basically, our bodies are the most powerful doctors and medicines, so the role of nurses in maintaining immunity through increasing the knowledge of sufferers how adaptive coping is very necessary. Nurses are expected to maximize the provision of HE (Health Education) regarding the body's natural abilities, especially regarding the activity of body cells that occur when we can manage existing stress so that relapses can be avoided with the right and correct coping mechanisms. From the description above, the authors are interested in examining whether there is a relationship between coping mechanisms and recurrence frequency in patients with bronchial asthma.

\section{MATERIALS AND METHODS}

This research is a Non-Experimental Correlational Analytical Study Design because this research describes a relationship, estimates, tests based on existing theories. And aims to reveal the correlative relationship between variables. Nonexperimental because special research is not treated for variables, only observations, measurements, of variables and indicators, are carried out using the point time approach (crosssectional).

In this study, the population was 35 people with bronchial asthma at the M. Noer Pamekasan Hospital. This study uses the Probability Simple Random Sampling technique. Namely, the sample that met the inclusion criteria was drawn by lot, namely 36 respondents (Nursalam, 2016). The sample used as the subject of this study amounted to 35 respondents.

\section{RESULTS}

Table 1 Characteristics of Respondents Based on Coping Mechanisms in Patients with Bronchial Asthma

\begin{tabular}{|c|c|c|c|}
\hline No & Coping Mechanism & Total (n) & Percentage (\%) \\
\hline 1 & Maladaptive & 22 & 62,9 \\
\hline 3 & Adaptive & 13 & 37,1 \\
\hline \multicolumn{2}{|c|}{ Total } & 35 & 100 \\
\hline
\end{tabular}

According to the table above, most respondents have a maladaptive coping mechanism with $62.9 \%$ 
Table 2. Characteristics of Respondents Based on the Frequency of Recurrence in Bronchial Asthma Patients.

\begin{tabular}{cccc}
\hline No & $\begin{array}{c}\text { Frequency of } \\
\text { Recurrence }\end{array}$ & Total (n) & Percentage (\%) \\
\hline 1 & $>5 X /$ month & 25 & 71,4 \\
2 & $1-4 X /$ month & 10 & 28,6 \\
\hline & Total & 35 & 100 \\
\hline
\end{tabular}

Shows that most of the respondents have a recurrence frequency $>5 \mathrm{x} /$ month, namely $71.4 \%$

Table 3. Characteristics of respondents based on the relationship between coping mechanisms and recurrence frequency in bronchial asthma patients

\begin{tabular}{cccc}
\hline Freq. Recurrence & 1-4X/Month $\%$ & $\mathbf{5}$ X/month \% & Total (\%) \\
\hline CM & $4(11,4 \%)$ & $9(25,6 \%)$ & $13(37,1 \%)$ \\
Adaptive & $6(17,2 \%)$ & $16(45,7 \%)$ & $22(62,9 \%)$ \\
\hline Maladaptive & $10(28,6 \%)$ & $25(61,4 \%)$ & $35(100 \%)$ \\
\hline
\end{tabular}

Shows that almost half of the respondents have a maladptive coping mechanism and a recurrence frequency of $.5 x$ / month, and a small proportion of respondents have an adaptive coping mechanism and a recurrence frequency of $.5 x /$ month, namely $11.4 \%$.

\section{DISCUSSION}

Coping Mechanism in Bronchial Asthma Patients, based on the table, data on the coping mechanisms used by bronchial asthma patients who took medication to the M. Noer Pamekasan Hospital in 2018, both inpatients and outpatients (poly), most of them (62.9\% or 22 people) had a maladaptive mechanism and nearly half $(37.1 \%$ or 13 people) had adaptive coping mechanisms.

The coping mechanism is divided into two, namely adaptive and maladaptive. The adaptive coping mechanism supports the integration function. This adaptive coping mechanism is expected to be able to reduce the risk of the incidence of depression in final year students who are undergoing the thesis process. On the other hand, the maladaptive coping mechanism is something that hinders the integration function (S. Stuart, 2006). The success of the coping mechanism used will determine the degree of stress that is felt. The use of this type of coping mechanism is declared effective if it can overcome sources of stress (Rachmah \& Rahmawati, 2019)

Coping mechanisms are the various efforts made by individuals to cope with the stress they face (G. . Stuart \& Laraia, 2009). According to Lazarus and Folkman, the coping mechanism is a constant change of cognitive and behavioral efforts to organize external and internal demands which are considered as burdensome or exceeding individual resources. According to research, the incidence of asthma has a significant relationship with a person's anxiety condition (Lestari et al., 2014). This is in accordance with research conducted by Lieshout \& McQueen which states that one of the triggers for bronchial asthma attacks is an unstable psychological condition. These psychological conditions, such as stress, have an important role in the recurrence of bronchial asthma. Based on the results of the study, there were 19 subjects who said that their asthma recurred when they were stressed (Lieshout \& McQueen, 2008).

From the existing data (almost half of $45.7 \%$ of the sample have primary school education) it can be seen that the Madurese community, especially bronchial asthma patients who went to M. Noer Pamekasan Hospital in 2018, have a maladaptive coping mechanism which is a result of low education. This indicates how much the community needs health education. So based on this, we cannot rule out that health education, especially regarding coping mechanisms, is also important. It is hoped that in the future, there will be shifts in a positive direction.

Frequency of Recurrence in Bronchial Asthma Patients, based on table 4.6, it is found that the distribution of respondents based on the frequency of recurrence in bronchial asthma patients at M. Noer Pamekasan Hospital in 2018 most $(71.4 \%$ or 25 people) experienced recurrence $>5 \mathrm{X} /$ month, and almost half $(28.6 \%$ or 10 people) experienced recurrences $1-5 \mathrm{X} /$ month.

An asthma attack occurs when a person who is atopy is exposed to an allergen present in the daily environment and forms immunoglobulin $\mathrm{E}(\mathrm{IgE})$. The atopy factor is inherited. Allergens that enter the body through the respiratory tract, skin, and others will be caught by macrophages that work as antigen-presenting cells (APC). After the allergens have been processed in APC cells, the 
allergens are presented to Th cells. The cells signal $B$ cells by releasing interleukin 2 (IL-2) to proliferate into plasma cells and form immunoglobulin E (lgE) (Miglino et al., 2011).

The formed IgE will be bound by mastocytes in the tissue and basophils in the circulation. When this process occurs in a person, that person is already sensitized or is just becoming vulnerable. If the already susceptible person is exposed to the same allergen twice or more, the allergen will be bound by lgE that is already on the surface of the mastoid and basophils. This bond will cause $\mathrm{Ca}++$ influx into cells and changes in cells that reduce CAMP levels (Sukamto, 2010).

A decrease in CAMP levels leads to cell degranulation. This cell degranulation will cause the release of chemical mediators which include: histamine, slow-releasing substance of anaphylaxis (SRS-A), eosinophilic homothetic factor of anaphylactic (ECF-A), and others. This will cause three main reactions, namely: contraction of smooth muscles both large and small airways which will cause bronchospasm, increased capillary permeability which plays a role in the occurrence of mucosal edema which increases the narrowing of the airways, increased secretion of mucous glands, and increased mucus production. These three reactions cause impaired ventilation, uneven distribution of ventilation with pulmonary blood circulation, and impaired gas diffusion at the alveolar level, resulting in hypoxemia, hypercapnia, and acidosis at a very advanced stage.

According to Nurulistyawan's research on asthma recurrence, it was found that factors related to asthma recurrence were knowledge, attitudes, anxiety, and socioeconomic conditions (Nurulistyawan T.P, 2011). In addition, the trigger factors are stress and anxiety. The results show that there is a significant relationship between stress and the frequency of recurrence in women with bronchial asthma in early adulthood (Lestari et al., 2014). This is in accordance with research conducted by Lieshout \& McQueen (2008) which states that one of the triggers for bronchial asthma attacks is an unstable psychological condition. These psychological conditions, such as stress, have an important role in the recurrence of bronchial asthma.

Asthma attacks can be divided clinically into three stages. The first stage is characterized by periodic dry coughs. This cough occurs due to mucosal irritation that is thick and clumps up. At this stage, there is edema and swelling of the bronchi. The second stage is characterized by coughing with clear, frothy mucus. The client feels short of breath, tries to breathe deeply, elongated expiration followed by a wheezing sound (Dinakar et al., 2017). The client prefers to sit with his hands resting on the edge of the bed, the patient looks pale, restless, and the skin color around starts to turn blue. While the third stage is characterized by almost no sound of breath being heard due to small airflow, no coughing, shallow and irregular breathing, high respiratory rhythm due to asphyxia (Sukamto, 2010). In this case, the frequency of recurrence in bronchial asthma patients at M. Noer Pamekasan Hospital in 2018 is divided into two categories, namely: $>5 \mathrm{X} /$ month, and $1-5 \mathrm{X} /$ month.

After conducting a study at the M. Noer Pamekasan Hospital, it was found that a very significant difference in the number of patients who relapsed $>5$ times/month with patients who relapsed was only $1-4 \mathrm{X} /$ month. Therefore, this requires more attention to the cause, so that it is expected to reduce the incidence that is so high in patients who experience recurrence $>5 \mathrm{X} /$ month.

The Relationship between Coping Mechanism and Recurrence Frequency in Bronchial Asthma Patients, based on the table, it is found that almost half of patients with bronchial asthma who went to M. Noer Pamekasan Hospital in 2018 (45.7\% or 16 people) had a maladaptive coping mechanism and relapsed $>5 \mathrm{X} /$ month, and some (14.3\% or 5 people) have adaptive coping mechanisms and relapse 1-5X / month.

Based on the analysis of the Rank Spearman statistical test using the SPSS16 program, the Correlation Coefficient value $=0.430$ and Sig $=0.010$. Because $0.010<0.05, \mathrm{HO}$ is rejected and $\mathrm{H} 1$ is accepted. This means that there is a relationship between the coping mechanism and the frequency of recurrence in bronchial asthma patients at M. Noer Pamekasan Hospital in 2018.

It is a common phenomenon when something negative produces something negative as well, as well as the coping mechanisms that exist in each individual. According to Stuart, coping mechanisms are all efforts directed at managing stress which can be constructive and destructive (G. . Stuart \& Laraia, 2009). When the maladaptive coping mechanism controls more than the adaptive coping mechanism in one individual, then as a consequence of that, more frequent recurrences cannot be avoided (Hawari, 2011).

Emotional stress is one of the triggers for asthma attacks, but it can also aggravate existing asthma attacks. In addition to the symptoms of asthma that arise, people with asthma who experience stress / emotional disturbances should immediately be treated with advice to solve their personal problems. Because if the stress has not 
been resolved, the asthma symptoms cannot be treated (Rosyidi \& Wulansari, 2013). The results of research on the effect of stress management training on psychological well-being in asthma sufferers found that there was no significant difference in psychological well-being scores between the experimental group and the control group after being given stress management training in the experimental group. This is related to the qualitative analysis which shows a positive transformation in the experimental group such as increased psychological function and physical health in bronchial asthma patients (Putrikita, 2018)

Researchers have found that the cumulative wear and tear of stress can result in a detrimental allostatic-toll physiological load on the body that can affect a child. In addition to general physiological burdens, the effects of stress on biological systems relevant to specific diseases have implications for disease. Sandberg et al studied the effect of positive experiences on the relationship between stress and asthma in children. In a previously reported cohort, they assessed whether life events involving a large positive effect on children could protect against the increased risk associated with stressful life events. They show that life events with definite positive effects can counteract an increased risk of asthma exacerbations. (Bloomberg \& Chen, 2005)

Other studies on asthma relapse have also been related to social support and selfacceptance of asthma. Self-acceptance is one of the manifestations of adaptive coping mechanisms. From the results of the study, it can be concluded that there is a positive relationship between family social support and the selfacceptance of individuals who have asthma (Utami \& Widiasavitri, 2013)

\section{CONCLUSION}

1) Most patients with bronchial asthma experience recurrence of more than $5 \mathrm{X} / \mathrm{month}$.

2) Most patients with bronchial asthma have a maladaptive coping mechanism.

3) From the results of statistical tests with Rank Spearman SPSS16.0, it is found that the Correlation Coefficient analysis $=0.430$ and Sig $=0.010$. Because $0.010<0.05, \mathrm{H} 0$ is rejected and $\mathrm{H} 1$ is accepted, which means there is a relationship between the coping mechanism and the frequency of recurrence in bronchial asthma patients.

\section{REFERENCES}

Bloomberg, G., \& Chen, E. (2005). The relationship of psychologic stress with childhood asthma. Immunol Allergy Clin North Am, 25, 83-105.

Bustam, F. P. (2015). Hubungan antara Obesitas dengan Asma Bronkial. 2 (4), 481-485.

Dinakar, C., Chipps, B. E., Matsui, E. C., Abramson, S. L., Irani, A. M., Kim, J. S., Mahr, T. A., Pistiner, M., Wang, J., Katkin, J. P., Van Hook, K. N., Brooks, L. J., Hudak, B. B., Kravitz, R. M., Paranjape, S., Schechter, M. S., Sharma, G. D., \& Stokes, D. C. (2017). Clinical tools to assess asthma control in children. Pediatrics, 139(1). https://doi.org/10.1542/peds.2016-3438

GAN, T. G. A. R. (2018). New Zealand: Global Asthma Network. 2014.

Hasan, N., \& Rufaidah, E. R. (2013). Hubungan antara dukungan sosial dengan strategi Coping pada penderita stroke rsud dr. Moewardi Surakarta. Talenta.

Hawari, D. (2011). Manajemen Stres Cemas Dan Depresi. FKUI.

Lestari, N. F., Hartini, N., \& Kes, M. (2014). Hubungan Antara Tingkat Stres dengan Frekuensi Kekambuhan pada Wanita Penderita Asma Usia Dewasa Awal yang Telah Menikah. JURNAL Psikologi Klinis Dan Kesehatan Mental, 2(1), 7-15.

Lieshout, R. J., \& McQueen, G. (2008). Psychological Factors in Asthma. Alergy, Asthma, and Clinical Immunology, 12-28.

Miglino, N., Roth, M., Tamm, M., \& Borger, P. (2011). House dust mite extract downregulates $\mathrm{C} / \mathrm{EBPa}$ in asthmatic bronchial smooth muscle cells. Eur Respir J, 38, 50-58.

Nursalam, N. (2016). Metodologi Penelitian IImu Keperawatan. Salimba Medika.

Nurulistyawan T.P. (2011). Faktor-Faktor Yang Berhubungan Dengan Kekambuhan Asma Bronkhiale Pada Pasien Rawat Jalan Di Poli Paru Instalasi Rawat Jalan RSUD RAA Soewondo Pati. 201. http://garuda.ristekdikti.go.id/search/do cument?q=asma+bronkhial+

Putrikita, K. A. (2018). Pengaruh Pelatihan Manajemen Stres terhadap Kesejahteraan Psikologis pada Penderita Asma. Universitas Islam Indonesia.

Rachmah, E., \& Rahmawati, T. (2019). Hubungan Pengetahuan Stress Dengan Mekanisme Koping Remaja. Dinamika Kesehatan Jurnal Kebidanan Dan Keperawatan, 10(2), 595-608. https://doi.org/10.33859/dksm.v10i2.517

Rosyidi, K., \& Wulansari, N. D. (2013). Prosedur Praktik Keperawatan. Jilid 1. CV. Trans Info Media.

Soetjiningsih. (2015). Infodatin-Asma.Pdf. In you can control your Asthma. 
Stuart, G. ., \& Laraia, M. . (2009). Principle and Practice of Psychiatric Nursing. Mosby.

Stuart, S. (2006). Buku Saku Keperawatan Jiwa. 3rd ed (3rd ed.). EGC.

Sukamto, H. S. (2010). Asma Bronkial. In Buku AJar Penyakit Dalam (Issue 0902005081).
Utami, N. M. S. N., \& Widiasavitri, P. N. (2013). Hubungan Antara Dukungan Sosial Keluarga dengan Penerimaan Diri Individu yang Mengalami Asma. Jurnal Psikologi Udayana, 1(1), 12-21. https://doi.org/10.24843/jpu.2013.v01.i0 1.p02 